\title{
Ontogenetic changes in the diet of the coral reef grouper Plectropomus leopardus (Serranidae): patterns in taxa, size and habitat of prey
}

\author{
Jill St John* \\ Department of Marine Biology, James Cook University, Townsville 4811, Australia
}

\begin{abstract}
Stomach contents and diet of a wide range of sizes (4.7 to $57.3 \mathrm{~cm}$ standard length [SL]) of the predatory coral trout Plectropomus leopardus (Fam. Serranidae) collected mostly from the northern Great Barrier Reef during the summers of 1991 and 1992 were examined. Overall, 422 prey in 28 families of fishes were identified of which 3 families, Clupeidae, Pomacentridae and Labridae, represented more than $60 \%$ of the diet. Average daily consumption of prey in P. leopardus was $2.8 \%$ of relative body weight and fish of 20 to $49.9 \mathrm{~mm}$ SL were eaten by all size classes. Juvenile (up to $20 \mathrm{~cm}$ SL) and adult $P$. leopardus have distinct diets. The major dietary shift in the type, species composition, length and shape of prey occurs at approximately $20 \mathrm{~cm} \mathrm{SL}$, just prior to the onset of maturity. Juveniles consumed a high proportion of benthic dwelling crustaceans, mostly penaeid shrimps, whereas adults were almost entirely piscivorous. The number of families of fishes in the diet did not increase with the size of predator as some families were eaten exclusively by juveniles or adults. Abundances of fish families in the diet varied ontogenetically and among size classes in small adults. Predation was related to size of prey in juvenile and small adults. Up to $35 \mathrm{~cm} \mathrm{SL}$, the range of prey sizes widened with increases in predator length, as larger fish ate larger prey, concomitantly feeding on small fishes, especially schooling species. However, the composition of the diet and length of fish prey did not change in $P$. leopardus after $35 \mathrm{~cm} \mathrm{SL}$ and prey did not deepen after $45 \mathrm{~cm}$ SL. Body depth of prey was more important than length in size-related feeding on 2 common families of fishes with different shapes. In general, larger $P$. leopardus appeared to feed optimally on deep-bodied fish, whereas juveniles avoided gape limitation by consuming more slender fish. All size-related predation in P. leopardus, however, was easily decoupled by the presence of highly abundant small fishes in large visible schools.
\end{abstract}

KEY WORDS: Feeding ecology Coral reef fish - Serranidae - Dietary analyses - Size-related predation

\section{INTRODUCTION}

Coral reefs are one of the richest environments for fishes on earth (Sale 1991) as 30 to $40 \%$ of all fish species live in this habit (Cohen 1970). The Great Barrier Reef (GBR) in Australia is the largest coral reef system in the world, covers nearly $2500 \mathrm{~km}$ in a north-south direction (Latitude $9^{\circ} \mathrm{S}$ to $24^{\circ} \mathrm{S}$ ) and is home to approximately 1500 species of fish (Randall et al. 1990). Among the largest piscivorous bony fishes on the GBR are the

\footnotetext{
- Present address: Ishigaki Tropical Station, Seikai National Fisheries Research Institute, 148-446, Fukai-Ohta, Ishigakishi, Okinawa 907-0451, Japan

E-mail: jstjohn@snf-its.affrc.go.jp
}

coral trouts (Family Serranidae, genus Plectropomus). The coral trout fishery is the most valuable fin-fishery on the GBR (Williams \& Russ 1994), representing about $30 \%$ of the total catch of the commercial line-fishing industry in Queensland (4000 metric tonnes in 1989, Trainor 1991). Due to their commercial importance, research on the biology of coral trouts has recently received much attention on the GBR (Doherty et al. 1994, Ferreira \& Russ 1994, 1995, Russ et al 1996, Light \& Jones 1997, Samoilys 1997, Zeller 1998) and much of this work has focused on the adults in the fishery (but see Doherty et al 1994, Light 1995, Light \& Jones 1997). Yet, information on all stages of their life history is necessary to understand the ecology of coral trouts. This study focuses on ontogenetic changes in their diet. 
Most demersal fishes undergo size-dependent shifts in their diet after settlement into the reef population. The particular pattern of these shifts in food use has important ecological ramifications for the species (Werner \& Gilliam 1984). For example, is the food niche of smaller size classes isolated from, or included in, that of larger size classes? If individuals of the same species are trophically distinct at different life stages, then fluctuations in the abundances of new individuals recruiting into the population will have no trophic effects.

Within species, diets of fish of differing sizes may vary in the type of prey eaten, their taxonomic richness of the diet or in size and shape of prey. On coral reefs, dietary shifts have been caused by changes in feeding behaviour or habitat of the predator (Austin \& Austin 1971). In general, however, morphological feeding limitations most frequently explain differences in fish diets (Mummert \& Drenner 1986). Most piscivorous fishes are gape-limited because they swallow prey whole and the size of prey selected is determined by the mouth size of the predator (Werner 1974, 1977, Zaret 1980, Galis 1993).

Size selection of prey by the predator has been assessed by using length of prey (see Reshetrikov et al. 1972 for the tropical serranids, Epinephelus spp.). Recently, however, body depth of prey has been considered to be a more useful measure for examining prey size selection by gape-limited predatory fish (Hambright 1991). The degree to which predators can engulf prey close to their gape size varies among species (Schael et al. 1991). Within species, the degree of gape limitation can vary with increases in body size as gape is a function of the length of the predatory fish. Smaller size classes of a species are expected to be more gape limited than larger size classes, which can consume a wider range of prey. Variations in gape limitation can occur abruptly with major dietary shifts to different prey taxa, or gradually as a wider variety of prey in the habitat becomes available to the predator (Werner \& Gilliam 1984). Size dependent changes in the diet of piscivorous fish should not be examined without considering gape limitation because it is inextricably linked to their diet.

To date there is nothing known about gape limitation in coral reef piscivores. Gape-size of piscivores has not been related to the shape of their prey even though oval and deep-bodied fishes are abundant in coral reef fish assemblages. Only 3 studies of gut contents of predatory fishes on coral reefs have examined sizerelated patterns in the diet (Kingsford 1992, Light 1995. Connell 1998) but these have not examined ontogenetic changes in the diet at different life history phases of the predator

Plectropomus leopardus (Lacepede, 1802) is the most widespread and abundant species of coral trout on the
GBR (Randall \& Hoese 1986). Even in the northern GBR, where populations of Plectropomus leopardus are smaller, densities average 3 to 4 fish per $1000 \mathrm{~m}^{2}$ (Ayling \& Ayling 1992). Their post-larvae settle on coral reefs at about $20 \mathrm{~mm}$ total length (TL) (Leis 1987) on coral rubble substrata (Light \& Jones 1997), and adults can grow up to $1 \mathrm{~m}$ in size (Randall et al. 1990). As these predators are large (asymptotic length $\left[\mathrm{L}_{\infty}\right]=$ $68 \mathrm{~cm}$ fork length [FL], Ferreira \& Russ 1995) and highly mobile (movement along reefs averages $2 \mathrm{~km}$, Samoilys 1997), potential prey for P. leopardus would include fishes of all sizes from most habitats on coral reefs.

A few studies have examined the diet of adult (Choat 1968, Goeden 1978, Kingsford 1992) and juvenile (Light 1995) Plectropomus leopardus on the GBR. Up to $1 \mathrm{yr}$ of age, juvenile $P$. leopardus feed mainly on benthic invertebrates (Crustacea) and less on small, demersal fishes (Goeden 1978, Light 1995), and small $P$. leopardus $(<20 \mathrm{~cm} \mathrm{SL})$ in the lagoon of One Tree Reef consumed more crustaceans (Kingsford 1992). Adult $P$. leopardus, however, are highly piscivorous (Choat 1968, Kingsford 1992). All of these studies examined $P$. leopardus at 1 reef only, and, except for Light (1995), with relatively small sample sizes. The 2 major aims of this study are: (1) to describe how the diet of $P$. leopardus changes with a more than 10 -fold increase in size (5 to $58 \mathrm{~cm} \mathrm{SL),} \mathrm{and} \mathrm{(2)} \mathrm{to} \mathrm{relate} \mathrm{preda-}$ tor size to prey size using several measurements of predator and prey. Gape limitation and shape of prey are investigated.

\section{METHODS}

Plectropomus leopardus. Collections: To examine ontogenetic patterns in the diet of this predator, specimens were collected from reefs in 5 areas of the GBR (Table 1). All of the samples were collected in summer (November 1991 to February 1992), except for a few juveniles that were collected in spring 1990 (Gladstone sample, Table 1). Although most Plectropomus leopardus were speared, some were hooked by handlines, captured using fence nets or poisoned with rotenone (Table 1).

Only undigested prey provided accurate measurements of size and weight of prey. As approximately $10 \%$ of prey were undigested, $20 \%$ of prey were partially digested and 30 to $40 \%$ of the stomachs of Plectropomus leopardus were empty (St John 1995), a large number of predators were required to examine relationships between prey and predator size. Thus, this data was collected from a large sample of $2500 \mathrm{P}$. leopardus, ranging in size from 4.7 to 70.5 (cm SL), collected on the GBR between 1990 and 1993. 
Table 1. Plectropomus leopardus. Collections of the 1076 specimens used in the ontogenetic study

\begin{tabular}{|c|c|c|c|c|c|}
\hline $\begin{array}{l}\text { Size-r } \\
\text { specil } \\
\text { (cm } \\
\text { min. }\end{array}$ & $\begin{array}{l}\text { range of } \\
\text { mens } \\
\text { SL) } \\
\text { max. }\end{array}$ & $\begin{array}{l}\text { Sample } \\
\text { size }\end{array}$ & $\begin{array}{c}\text { Location } \\
\text { (nearest } \\
\text { town) }\end{array}$ & $\begin{array}{l}\text { Method of } \\
\text { collection }\end{array}$ & Year \\
\hline 5.7 & 16.0 & 240 & Cairns & Spear & 1991,1992 \\
\hline 6.0 & 13.0 & 6 & Gladstone & Rotenone & 1990 \\
\hline 12.5 & 25.5 & 9 & Lizard Is. & Fence net & 1991,1992 \\
\hline 10.5 & 51.0 & 520 & Innisfail & Spear & 1992 \\
\hline 24.8 & 52.1 & 301 & Townsville & Spear & 1991,1992 \\
\hline
\end{tabular}

Measurements, morphometric relationships and gape: Whole Plectropomus leopardus were weighed to the nearest gram. FL and SL were measured to the nearest 1 or $5 \mathrm{~mm}$. Morphometric relationships in $P$. leopardus were calculated and used either to estimate weights of specimens from their length, or to convert FL. measurements to SL.

The length-weight relationship was calculated using Plectropomus leopardus ranging in size from $4.7 \mathrm{~cm} \mathrm{SL}$ $(5.7 \mathrm{~cm} \mathrm{FL})$ to $57.3 \mathrm{~cm} \mathrm{SL}(66.3 \mathrm{~cm} \mathrm{FL})$ and weighing from $3 \mathrm{~g}$ to $4.750 \mathrm{~kg}$ (wet-weight, Table 2) and was found to be similar to collections of $P$. leopardus from the northern GBR regions (Ferreira \& Russ 1994).

The SL and FL (cm) and gape size (mm) were measured in 64 Plectropomus leopardus of various sizes. Gape size in $P$. leopardus is defined as the narrowest lateral measurement inside the mouth/throat area and was measured to the millimetre using modified callipers. The gape size of $P$. leopardus increased linearly with its length (Regression $F_{[1,62]}=1417.42, \mathrm{p}<0.01$ $\log _{[10]}$ transformed data, Fig. 1).

Size classes: Plectropomus leopardus were divided according to SL $(\mathrm{cm})$ into size classes of 5 and $10 \mathrm{~cm}$ intervals. The sample sizes of 9 size classes of $5 \mathrm{~cm}$ intervals $(<10,10$ to $14.9,15$ to $19.9,20$ to $24.9,25$ to $29.9,30$ to $34.9,35$ to $39.9,40$ to 44.9 and 45 to 54.9 ), except the last, ranged from 36 to 260 (see Table 4). Plectropomus leopardus were divided into 3 groups:

Table 2. Plectropomus leopardus. Morphometric relationships between FL, SL $(\mathrm{cm})$ and weight $(\mathrm{kg})$ of specimens. Relationships are of the form $W=a L^{b}$ and $S L=a+F L$. $b$ : With sample size $n$ and $r^{2}$ Standard errors (SE) are in parentheses

\begin{tabular}{|lccccc|}
\hline$y$ & $x$ & $a$ & $b$ & $n$ & $r^{2}$ \\
\hline Log weight & Log FL & -11.16 & 3.00 & 426 & 0.99 \\
& & $(0.046)$ & $(0.013)$ & & \\
Log weight & Log SL & -10.56 & 2.98 & 533 & 0.99 \\
& & $(0.028)$ & $(0.008)$ & & \\
SL & FL & -0.130 & 0.852 & 427 & 0.99 \\
& & $(0.145)$ & $(0.003)$ & & \\
\hline
\end{tabular}

juveniles $(<10,10$ to $14.9,15$ to $19.9 \mathrm{~cm} \mathrm{SL})$, adults (20 to $24.9,25$ to $29.9,30$ to $34.9 \mathrm{~cm} \mathrm{SL}$ ) and large adults ( 35 to $39.9,40$ to 44.9 and 45 to $54.9 \mathrm{~cm} \mathrm{SL})$. Five size classes of $10 \mathrm{~cm}$ intervals $(<15,15$ to $24.9,25$ to $34.9,35$ to 44.9 and 45 to $54.9 \mathrm{~cm} \mathrm{SL)}$ were used for most analyses of the fish diet because the number of identified prey was small.

Stomach contents. Preservation: Stomach contents were preserved in 2 steps. Prey specimens were fixed in a buffered formalin solution (10\% formal calcium acetate FCA), using approximately $10 \mathrm{ml}$ of FCA for every gram of stomach content. After a minimum of $7 \mathrm{~d}$, the stomach contents were then transferred to $70 \%$ ethanol for storage.

Categories: Five categories were used to describe the number of prey $(0,1,2,3, \geq 4)$ found in stomachs of Plectropomus leopardus.

Fish prey. Identification: Prey fish in the diet of Plectropomus leopardus were identified to family level following the taxonomy of Randall et al. (1990) using either appropriate keys for undigested fish (Allen 1975, for Pomacentridae, Masuda et al. 1984, Myers 1991) or a key to genera and species based on dorsal and pectoral fin counts only (Smith \& Heemstra 1986). As many fishes were easily identified to family by dentition, biases in identifying prey were considered to be minor.

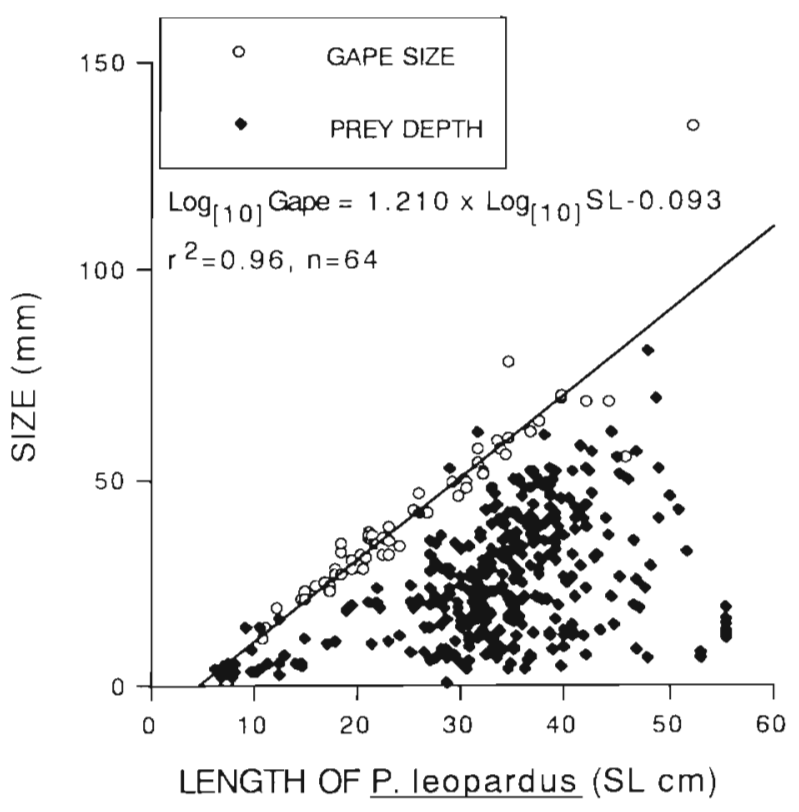

Fig. 1 Plectropomus leopardus. Gape size to fish length $(\mathrm{cm}$ SL) relationship (raw data). The depth of individual prey is plotted against length of $P$. leopardus (cm SL). Each point represents 1 prey item and may be one of up to 18 prey items in the stomach 
Measurement: The size of an individual prey item was described by weight and/or measurements of length and transverse section. The measurements taken for each prey depended on its degree of digestion. Undigested prey were weighed to the nearest $0.01 \mathrm{~g}$ Total length was measured to the nearest millimetre when at least 1 caudal fin lobe was intact. Standard length was measured to the nearest millimetre if the backbone of the prey was unbroken, or to the nearest $5 \mathrm{~mm}$ when the backbone and skull were present in pieces. Maximum body depth, defined as the largest transverse-dimension of the fish (i.e. the dorso-ventral measurement in most fish, or the width measurement in dorso-ventrally flattened fish), was measured, or estimated when the fish was slightly damaged by digestion, to the nearest millimetre.

A value to describe the shape of prey was calculated by dividing the body depth (defined earlier) by the SL using generalised diagrams of fish families in Randall et al. (1990). Slender fishes had low values (e.g. Synodontidae $=0.133$ ) and deep-bodied fishes had higher values (e.g. Pomacentridae $=0.556$ ) .

Size classes: As digestion usually damaged caudal fins, size classes of prey fish were based on SL (mm). Prey were divided into 23 size classes ranging from $<10$ to $220-229.9 \mathrm{~mm}$ SL.

Habitats: The reef environment was divided into 4 broad habitats: demersal and benthic reef substrata, midwater and adjacent sands. Families of prey fishes were classified by their use of habitat, i.e. where they were most commonly found (pers. obs.). Fishes in the 'demersal reef substrata' habitat swim around and above coral, but use it for shelter (e.g. Pomacentridae and Scaridae). Fishes categorised as using the 'benthic reef substrata' habitat were benthic dwellers, that remain very close to the substrata (e.g. Blenniidae and Tripterygiidae). Fishes categorised in the adjacent sands' dwell over, on, or within the sandy areas among reefs (e.g. Creedidae). Pelagic fishes in the 'midwater' habitat occurred from the surface to approximately $1 \mathrm{~m}$ over the reef (e.g. Clupeidae \& Caesionidae, Randall et al. 1990)

Relationships between predator and prey size. Weight: First, only undigested prey were included as they provided the most accurate weight measurements. Second, the prey was either the only, or the larger of 2 prey items in the stomach. In the latter, the largest prey was more than $90 \%$ of the total weight of stomach contents in most $(87 \%)$ of the stomachs. Relative prey weight ([prey weight/weight of Plectropomus leopardus $\times 100$ ) was calculated for $155 P$. leopardus ( $45 \%$ of predator weights were estimated from SL, see Table 2)

Predator gape and prey depth: Following Schael et al. (1991), a depth-gape value to describe the relation- ship between predator gape and prey depth was calculated by dividing depth of prey by gape size. The maximum possible depth-gape value is 1 and occurs when the depth of prey equals the gape of the predator that consumed it. Gape-limitation in a group of predators occurs when their mean depth-gape value of their larger prey is close to 1 (Schael et al. 1991). I tested the hypothesis that juveniles were gape-limited by comparing the largest $50 \%$ of depth-gape values in 5 size classes of Plectropomus leopardus. If the mean depth-gape value was higher in juveniles than in adults, then juveniles would be gape-limited.

Analyses of data: Frequency data in categories were compared using exact non-parametric tests for $\mathrm{r} \times \mathrm{c}$ tables because sample sizes were small or the data unbalanced (Mehta \& Patel 1992). Kruskal-Wallace $(K W)$ tests were used when 1 category was nominal and the other one was ordinal. Jonckheere-Terpstra $(J-T)$ tests were used when both categories were ordinal (Mehta \& Patel 1992). As the data sets were large and sparse, probability values were calculated using Monte Carlo methods. Probability values were based on 6000 iterations, exceeding Manly's (1991) recommendations

For parametric data, 1-way analyses of variance (ANOVAs) were used to compare sample means. Posthoc comparisons of means used Tukey's tests (Day \& Quinn 1989). Linear regressions were used when data were continuous. Two-way analyses of covariance (ANCOVAs) were used to compare means that had a covariate. Coefficients of the regression lines for each treatment group were compared using a $t$-test (Sokal \& Rohlf 1981) because the data did not fulfil the assumption of 'homogeneity of slopes' ([i.e. observed p \{interaction between the covariate and the treatment\} $<0.25$ ], Day \& Quinn 1989)

Prior to analysis of parametric tests, variances were tested for homogeneity using Cochran's test with balanced data or Bartlett's test with unbalanced data (Sokal \& Rohlf 1981). When data sets were heteroscedastic (i.e. one of the above tests was significant at $p<0.05$ ), appropriate transformations (see Underwood 1981) were done before the data was retested. In linear regressions, data were log transformed when not normally distributed (Wainwright 1988).

\section{RESULTS}

\section{Assessment of all stomach contents}

Number of prey

In 1076 Plectropomus leopardus captured during summer, $34 \%$ of the stomachs were empty, $49 \%$ con- 
tained 1 prey item and $17 \%$ had 2 or more prey items. In total, 1043 prey items were in the stomachs of 710 $P$. leopardus. The numbers of prey in stomachs of $P$. leopardus varied significantly among all size classes $\left(K W_{|8|}=35.92, \mathrm{p}<0.001\right.$, Fig. 2$)$, and less among adults $\left(\geq 20 \mathrm{~cm} \mathrm{SL}, K W_{|5|}=11.81, \mathrm{p}=0.037\right.$, Fig. 2). The smallest juveniles $(<10 \mathrm{~cm}$ SL) had the lowest proportion $(25 \%)$ of empty stomachs and the highest proportion $(42 \%)$ of stomachs containing 2 or more prey items. This pattern of feeding continued into the next size class (10 to $14.9 \mathrm{~cm} \mathrm{SL})$, with a small increase in the proportion of empty stomachs $(27 \%)$ and a decrease in the proportion of stomachs containing 2 or more prey items $(19 \%)$. Frequency of feeding in the largest juveniles (15 to $19.9 \mathrm{~cm} \mathrm{SL}$ ) appeared to be similar to adult $P$. leopardus. The 2 largest size classes ( 40 to 44.9 and 45 to $54.9 \mathrm{~cm} \mathrm{SL}$ ) rarely ate more than 2 items a day.

\section{Major groups of prey}

In total, 710 Plectropomus leopardus contained a total of 1043 prey items that were categorised into 3 major prey groups, fish (911), crustaceans (97) and cephalopods (12), and 23 unidentifed items which were excluded from the analyses. Eight pieces of hard coral and 2 foraminifera, that were found in the stomachs, were considered to have been ingested incidentally with prey.

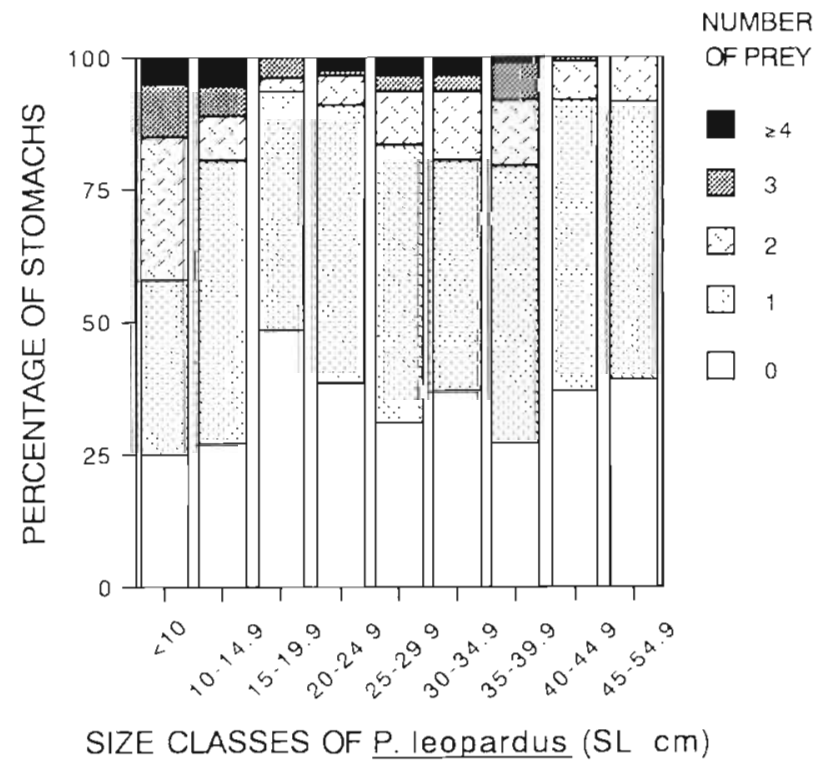

Fig. 2. Plectropomus leopardus. Number of prey per stomach in 9 size classes of $P$. leopardus $(<10,10$ to $14.9,15$ to 19.9 , 20 to $24.9,25$ to $29.9,30$ to $34.9,35$ to $39.9,40$ to 44.9 and 45 to 54.9). See Table 4 for sample sizes of $P$. leopardus

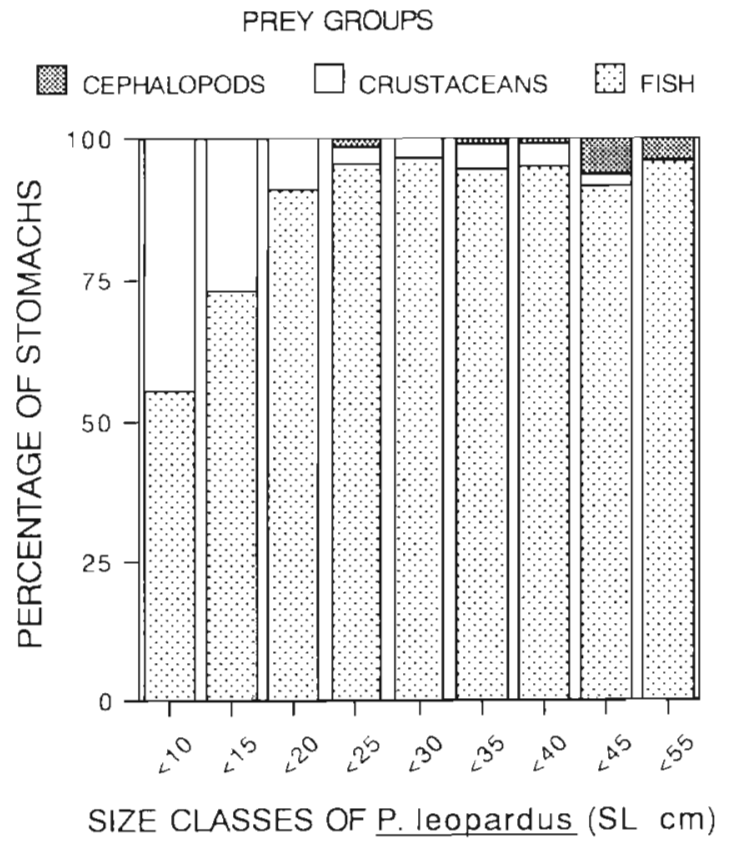

Fig. 3. Plectropomus leopardus. Predator-size related changes in gross dietary composition in the 9 size classes of $P$. leopardus $([\mathrm{n}=$ predator number, $\mathrm{p}=$ number of prey $],<10[52,99]$, 10 to $14.9[69,115], 15$ to $19.9[42,50], 20$ to $24.9[55,69]$, 25 to $29.9[108,154], 30$ to $34.9[163,270], 35$ to 39.9 [139, 201], 40 to $44.9[72,82]$ and 45 to $54.9[22,25])$ during summer

The proportion of fish and crustaceans differed among size classes $\left(K W_{|8|}=149.5, p<0.001\right.$, Fig. 3). Juveniles consumed more crustaceans, mostly penaeid shrimps, than adults, and the smallest size class $(<10$ $\mathrm{cm} \mathrm{SL}$ ) contained the highest proportion of crustaceans $(44 \%$, Fig. 3). Amongst larger size classes (15 to $54.9 \mathrm{~cm} \mathrm{SL})$, however, there was no difference in the proportion of fish and crustaceans consumed $\left(K W_{[6]}=\right.$ $4.380, p=0.625$, Fig. 3). Most of the 12 cephalopods were eaten by larger Plectropomus leopardus $1>30 \mathrm{~cm}$ SL).

As fishes dominated the diet of Plectropomus leopardus in all size classes (89\% numerically in diet, $95 \%$ in the adult ( $\geq 20 \mathrm{~cm} \mathrm{SL}$ ) diet), they were the focus of the rest of the results.

\section{Size relationships between predator and prey fish Weight}

As a rule, the weight of individual prey fishes increased with the weight of the predator, however, plectropomus leopardus of all sizes also consumed small prey. The majority of prey consumed by P. leopardus (under $2 \mathrm{~kg}$ ) weighed less than $0.1 \mathrm{~kg}$ and the largest prey item $(0.4 \mathrm{~kg})$ was found in a $3 \mathrm{~kg}$ fish. 


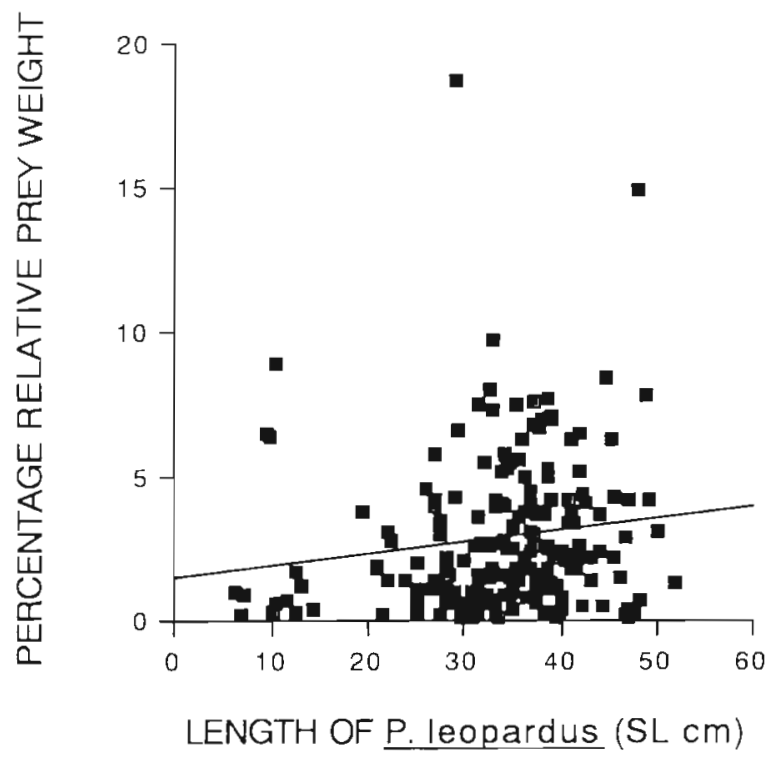

Fig. 4. Plectropomus leopardus. Relationship between predator length and relative prey weight (prey weight/predator weight $\times 100$ )

The mean relative prey weight (prey weight/weight of predator $\times 100$ ) was $2.8 \%$ and this ratio increased as the size of Plectropomus leopardus increased, although the relationship was weak (Regression $F_{[1,190]}=$ 5.281, $\mathrm{p}<0.05, \mathrm{r}^{2}=0.03, \log _{|10|}$ transformed data, Fig. 4).

\section{Length}

Each successive size class of Plectropomus leopardus, except the largest, consumed a significantly wider range of prey sizes than the previous size class (Fig. 5 , Table 3). Predators of all sizes ate prey from 20 to $49.9 \mathrm{~mm} \mathrm{SL}$, but only the smallest size class $(<15 \mathrm{~cm}$ SL) ate prey $<10 \mathrm{~mm}$ SL (Fig 5)

\section{Prey depth and predator gape}

The maximum depth of prey was smaller than the maximum gape size of its predator (Fig. 1) but for a few exceptions (probably caused by errors in measurement).

There were no size-dependent trends related to the gape-size of Plectropomus leopardus even though the depth gape value differed significantly between size classes $\left\{\right.$ ANOVA $F_{[4,176]}=11.38, p<0.01, \log _{[10\}}$ transformed data, Fig. 6). Gape limitation, if it occurred, would be expected in the smaller size classes, but the depth-gape value was significantly lower in the largest size class only (Tukey's pairwise comparisons, $p<0.03$,
Fig. 6). These large $P$. leopardus did not make use of their wide gape to eat prey with deeper bodies than the prey of smaller conspecifics.

\section{Shape of prey fishes}

The shape of the prey varied significantly among the 5 size classes of Plectropomus leopardus (ANOVA, $F=$

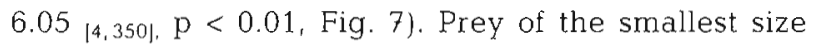
class of $P$. leopardus ( $<15 \mathrm{~cm}$ SL) were significantly narrower than prey in the larger size classes (Tukey's pairwise comparisons, $p<0.05$ ), except the largest (Tukey's pairwise comparisons, $p=0.14$, Fig. 7). Furthermore, the shapes of prey varied among the 4 habitats (ANOVA, $F=10.94$ [3.24\}, p < 0.01, Fig. 8). Prey in midwater and adjacent sandy habitats were significantly more slender than prey associated with the demersal reef substrata (Tukey's pairwise comparisons, $\mathrm{p}<0.01$ ). The slender shape of prey consumed by juveniles was not explained by the dominance of benthic prey in their diet because benthic prey did not significantly differ in shape from the prey in the other habitats.

\section{Size-related changes in the fish diet}

Abundances of prey per family in the diet

During summer, the diet of Plectropomus leopardus contained 422 prey in 28 families (Table 4). Three families, Clupeidae, Pomacentridae and Labridae, accounted for more than $60 \%$ of the diet numerically (Table 4).

Overall, the families eaten by Plectropomus leopardus varied ontogenetically $\left(K W_{|8|}=53.7, \mathrm{p}<0.001\right)$. Some families were eaten by juveniles exclusively (e.g. Tripterygiidae and Callionymidae) or in larger propor-

Table 3. Plectropomus leopardus. The results of Jonckheere Terpstra tests (Mehta \& Patel 1992) of paired comparisons of the size structure of the populations of prey fishes (mm SL) consumed by the 5 size classes of $P$. leopardus (cm SL). Comparisons are between adjacent size classes. $\cdots 1$ sided $p$-value $\leq 0.001_{i}$ ns $=$ not significant

\begin{tabular}{|c|c|c|c|}
\hline \multicolumn{2}{|c|}{$\begin{array}{l}\text { Paired comparisons } \\
\text { Size of } P \text {. leopardus }(\mathrm{cm} \mathrm{SL}\end{array}$} & $J$-T test statistic & \multirow[t]{2}{*}{ Significance } \\
\hline Group 1 & & & \\
\hline$<15$ & 15 to 24.9 & 7.662 & $\cdots$ \\
\hline 15 to 24.9 & 25 to 34.9 & 3.748 & $\cdots$ \\
\hline 25 to 34.9 & 35 to 44,9 & 7.472 & $\cdots$ \\
\hline 35 to 44.9 & 45 to 59.9 & 0.269 & ns \\
\hline
\end{tabular}




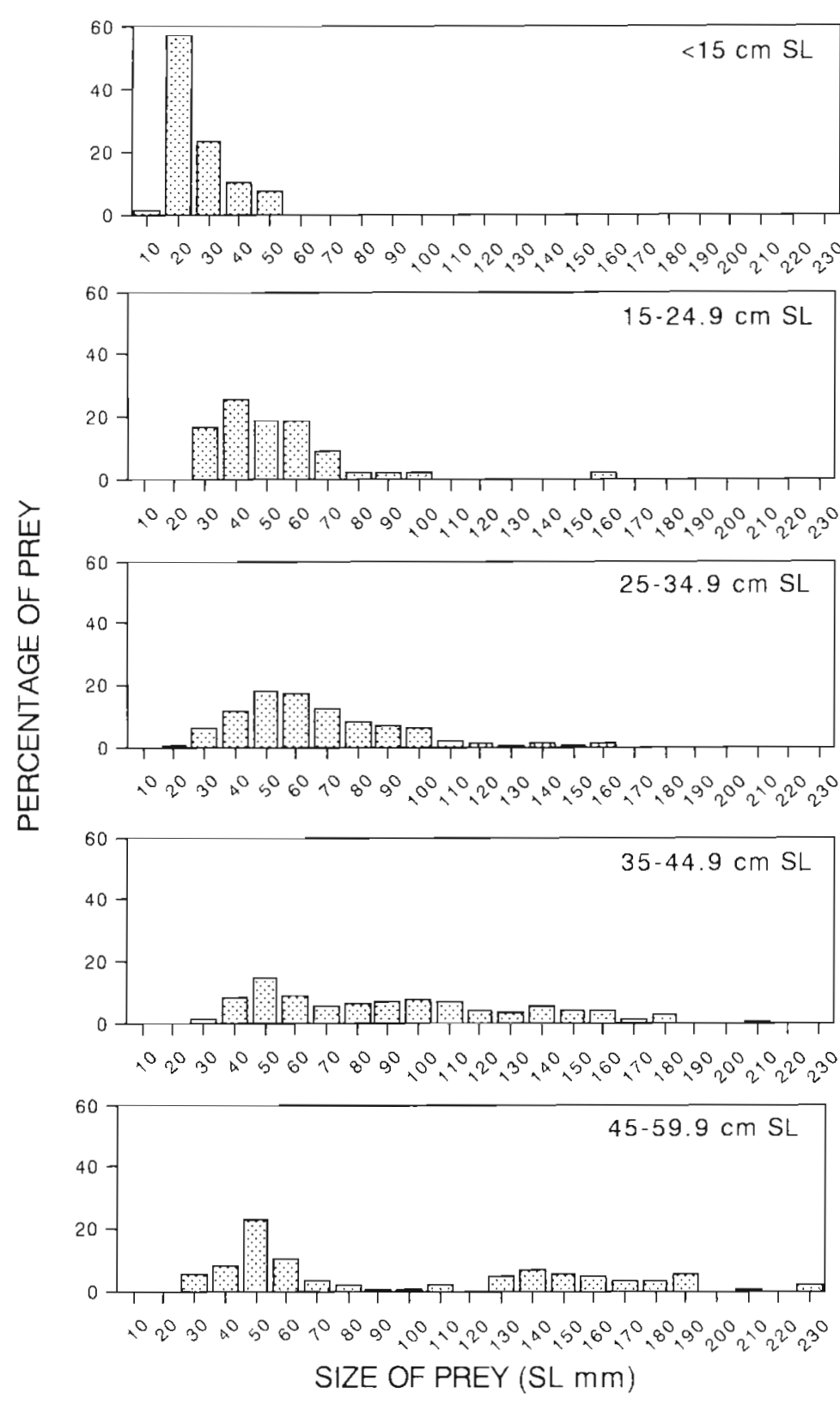

Fig. 5. Plectropomus leopardus. Length of prey (mm SL) consumed by the 5 size classes of $P$. leopardus $(<15,15$ to $24.9,25$ to $34.9,35$ to 44.9 and 45 to $54.9 \mathrm{~cm} \mathrm{SL}$ ). Prey were divided into 23 size classes ranging from $<10$ to $220-229.9 \mathrm{~mm}$ SL (depicted on the $x$-axis as 10 and 230, respectively)

As larger sample sizes improve the probability of detection of prey in the diet (Connell \& Kingsford 1997), species richness of the diet is expected to increase with sample size when a piscivore eats a wide variety of fish species. Thus the effect of differences in sample size (i.e. number of identified prey) among size classes of Plectropomus leopardus needed to be examined, particularly the size ranges with small samples. Samples were small in the size classes at both ends of the size range: juveniles and large adults. In juveniles there was no relationship between the number of identified prey and number of families in the diet (Fig. 9, Table 4). In large adults, however, the number of families in the diet increased with the number of identified prey in the sample (Table 4 , Fig. 9). But the composition of the diet did not vary among these size classes (Table 4 , Fig. 9), which suggested that the relationship between dietary composition and number of families in the diet for this size group was weak. In conclusion, the diet of juveniles and large adults were not unduly biased by small sample sizes

\section{Habitats of prey fishes}

The proportion of fish consumed from each habitat varied among the 9 size classes of Plectropomus leopardus $\left(K W_{[8]}=\right.$ 276.5, p<0.001, Fig. 10). Twelve of the 28 families of prey fishes were classified as demersal (Table 5), and demersal fishes dominated the diet of adults but for 2 size classes (25 to $34.9 \mathrm{~cm} \mathrm{SL}$ ) which consumed more midwater fishes (Fig. 10). Demersal fishes were least abundant in the diet of the smallest size class. Midwater fishes associated with reefs occurred in the diet of all but the 2 smallest size classes of $P$. leopardus and were the second largest component of the adult diet. Fishes

tions (e.g. Gobiidae). Other families were eaten only by adults (e.g. Caesionidae and Synodontidae, Table 4). Abundances of families in the diet differed most among the mid-range size classes of $P$. leopardus because diets were similar between adjacent size classes only (see Table 4 for statistical tests). There was no significant difference in abundances of families in the diet within 2 groups of $P$. leopardus: juveniles and large adults (see Table 4 ). dwelling on the sands adjacent to reefs and benthic dwellers on hard coral substrata were eaten least frequently (Fig. 10). Fishes of the adjacent sands appeared in small proportions in the diet $(<13 \%)$ of 7 size classes of $P$. leopardus (Fig. 10). Benthic fishes were the major component in the diet of the 2 smallest size classes $(<10 \mathrm{~cm} \mathrm{SL}-83.3 \%, 10$ to $14.9 \mathrm{~cm} \mathrm{SL}-$ $45 \%$, Fig. 10). In conclusion, juveniles ate less benthic and more demersal prey as they grew (Fig. 10). 


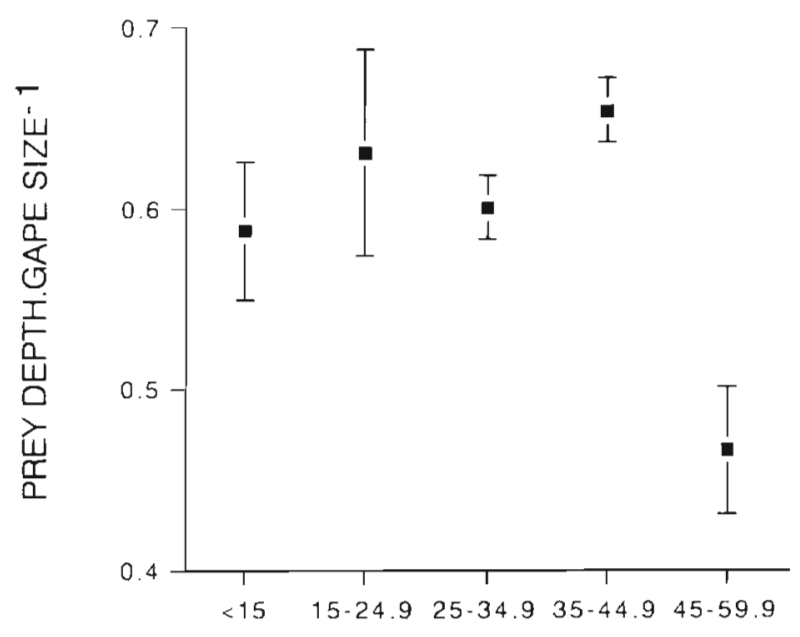

SIZE CLASSES OF P. leopardus ( $\mathrm{SL} \mathrm{cm}$ )

Fig. 6. Plectropomus leopardus. The mean tatio (and SE) of maximum depth of prey to gape size of predator for 5 size classes of P. leopardus (as in Fig. 5)

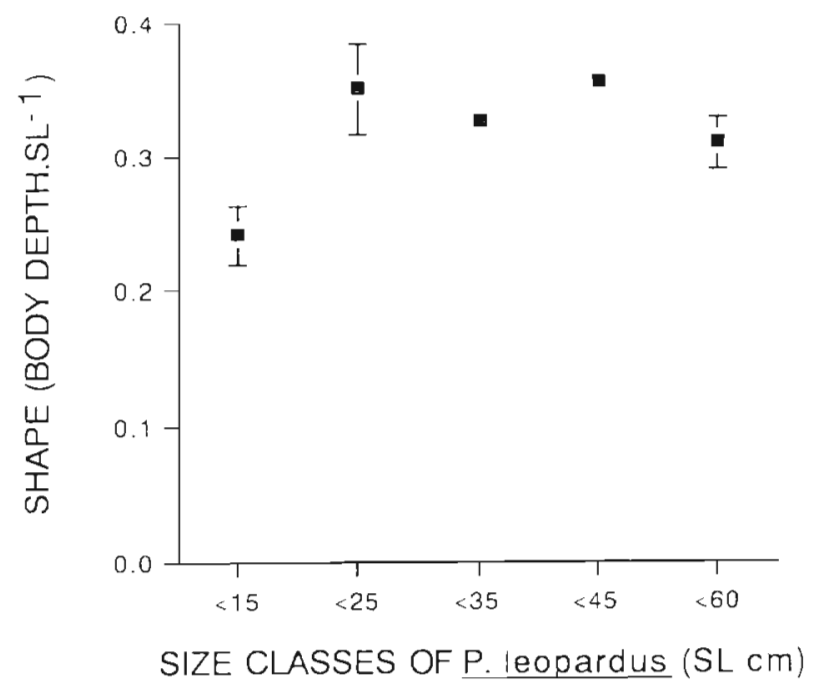

Fig. 7. Plectropomus leopardus. The mean and SE shape (maximum depth of prey/SL) of prey among the 5 size classes of $P$. leopardus

\section{Predation on families of prey fish in relation to their form or size}

In 2 common families, Pomacentridae and Caesionidae, eaten by large Plectropomus leopardus, prey were numerous enough to permit statistical comparisons. Prey shape was described by length and depth measurements. In each family, body depth increased with standard length of the prey fish (Pomacentridae: Regression $F_{\mid 1,127\}}=547.75, \mathrm{p}<0.01, \mathrm{r}^{2}=0.81$ and Cae-

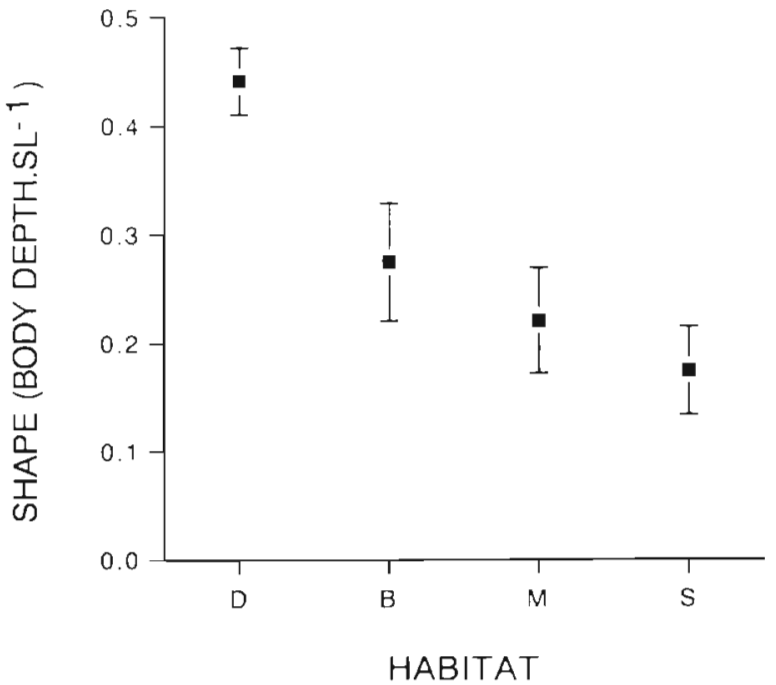

Fig. 8. The mean and SE shape (maximum deplin of prey/SL) of the prey of Plectropomus leopardus living in the 4 habitats, (D) demersal substrata, (B) benthic substrata, (M) midwater (S) and adjacent sands, (see methods for definitions)

sionidae: Regression $F_{[1,25]}=8.156, p<0.01, r^{2}=0.25$, $\log _{\mid 10\}}$ transformed data for both families, Fig. 11), but the average shape of the 2 families differed significantly $\left(t_{\left|i s_{2}\right|}=3.642, p<0.01\right.$, Fig. 11). Pomacentridae were elongate to oval, compressed fishes, whereas Caesionidae had slender, cylindrical bodies (Randall et al. 1990).

Relationships between the size of the predator and size of prey were investigated using the same 2 measurements of prey. In Pomacentridae, there was a significant relationship between. predator length and size of prey, in both SL and depth (SL: Regression $F_{[1,189]}=$ $68.47, \mathrm{p}<0.01, \mathrm{r}^{2}=0.27$, depth of prey: Regression $F_{|1,118|}=27.38, \mathrm{p}<0.01, \mathrm{r}^{2}=0.19$, both data sets $\log _{[10 \mid}$ transformed data, Fig 12). For Caesionidae, these relationships were not significant $\left(\mathrm{SL}: F_{[1,42]}=1.69, \mathrm{p}=\right.$ $0.201, \mathrm{r}^{2}=0.04$, depth of prey: $F_{|1,24|}=1.868, \mathrm{p}=0.184$, $r^{2}=0.07$, both data sets $\log _{[10 \mid}$ transformed data, Fig. 12). Overall, the length of Pomacentridae and Caesionidae consumed by Plectropomus leopardus differed significantly $\left(t_{[231]}=2.219, p<0.05, \log _{[10]}\right.$ transformed data) as predators consumed shorter Pomacentridae than Caesionidae (Fig 12a). The depth of prey consumed by $P$. leopardus, however, did not differ between families $\left(t_{|142|}=0.292, p>0.05, \log _{\mid 10\}}\right.$ transformed data, Fig. 12b).

\section{DISCUSSION AND CONCLUSIONS}

The length of Plectropomus leopardus increased more than 10-fold during the post-settlement phase on. 
Table 4. Plectropomus leopardus. The number and numerical percentage of prey (separated by '/') in each fish family consumed by the 9 size classes of $P$. leopardus. The total number of prey families, prey fishes and predators are recorded for each size class. Similarity in abundances of families in the diet among size classes is shown by dotted lines $\left(<10,10\right.$ to $14.9,15$ to $19.9, K W_{|2|}=$ $1.292, \mathrm{p}=0.529 ; 35$ to $39.9,40$ to 44.9 and 45 to $54.9, K W_{|2|}=1.50, \mathrm{p}=0.480 ; 20$ to 24.9 and 25 to $29.9, K W_{|1|}=1.59$, $\mathrm{p}=0.214 ; 25$ to 29.9 and 30 to $34.9, K W_{|1|}=2.30, \mathrm{p}=0.127 ; 30$ to 34.9 and 35 to $39.9, K W_{|1|}=1.23, \mathrm{p}=0.271$ )

\begin{tabular}{|c|c|c|c|c|c|c|c|c|c|c|}
\hline \multirow{3}{*}{$\begin{array}{l}\text { Prey } \\
\text { families }\end{array}$} & \multirow{3}{*}{$<10$} & \multicolumn{8}{|c|}{ Size of Plectropomus Jeopardus (cm SL) } & \multirow{4}{*}{$\begin{array}{c}\text { Total } \\
\text { number } \\
/ \%\end{array}$} \\
\hline & & 10 to & 15 to & 20 to & 25 to & 30 to & 35 to & 40 to & 45 to & \\
\hline & & 14.9 & 19.9 & 24.9 & 29.9 & 34.9 & 39.9 & 44.9 & 54.9 & \\
\hline \multicolumn{10}{|l|}{$\begin{array}{l}\text { Diet } \\
\text { similarity: }\end{array}$} & \\
\hline Clupeidae & & & $1 / 6.6$ & $3 / 14.3$ & $22 / 37.3$ & $56 / 44.1$ & $20 / 20.4$ & $5 / 13.5$ & $1 / 6.3$ & $108 / 25.6$ \\
\hline Pomacentridae & & $5 / 16.1$ & $3 / 20.0$ & $8 / 38.1$ & $11 / 18.6$ & $23 / 18.1$ & $28 / 28.6$ & $11 / 29.7$ & $4 / 25.0$ & $93 / 22.0$ \\
\hline Labridae & & $6 / 19.3$ & $3 / 20.0$ & $2 / 9.5$ & $6 / 10.2$ & $20 / 15.7$ & $11 / 11.2$ & $5 / 13.5$ & $4 / 25.0$ & $57 / 13.5$ \\
\hline Gobiidae & $12 / 66.7$ & $8 / 25.8$ & $1 / 6.6$ & $1 / 4.8$ & & $2 / 1.6$ & $2 / 2.0$ & & & $26 / 6.2$ \\
\hline Caesionidae & & & & & $6 / 10.2$ & $4 / 3.1$ & $8 / 8.2$ & $2 / 5.4$ & $2 / 12.5$ & $22 / 5.2$ \\
\hline Scaridae & & $1 / 32$ & & & $1 / 1.7$ & $2 / 1.6$ & $6 / 6.1$ & $8 / 21.6$ & $2 / 12.5$ & $20 / 4.7$ \\
\hline Synodontidae & & & & & $5 / 8.5$ & $5 / 3.9$ & $9 / 9.2$ & $1 / 2.7$ & & $20 / 4.7$ \\
\hline Blenniidae & $1 / 5.5$ & $4 / 12.9$ & $2 / 13.3$ & & $4 / 6.8$ & $2 / 1.6$ & $2 / 2.0$ & & & $15 / 3.5$ \\
\hline Atherinidae & & & & & & $7 / 5.5$ & $3 / 3.1$ & & & $10 / 2.4$ \\
\hline Apogonidae & & & $2 / 13.3$ & $5 / 23.8$ & $1 / 1.7$ & & $1 / 1.0$ & & & $9 / 2.1$ \\
\hline Serranidae & $1 / 5.5$ & & & $1 / 4.8$ & $1 / 1.7$ & & $3 / 3.1$ & $1 / 2.7$ & $1 / 6.3$ & $8 / 1.9$ \\
\hline Acanthuridae & $1 / 5.5$ & & & $1 / 4.8$ & & $1 / 0.8$ & $2 / 2.0$ & $2 / 5.4$ & & $7 / 1.6$ \\
\hline Tripterygiidae & $2 / 11.1$ & $3 / 9.7$ & & & & & & & & $5 / 1.2$ \\
\hline Callionymidae & $1 / 5.5$ & $3 / 9.7$ & & & & & & & & $4 / 0.9$ \\
\hline Engraulidae & & & & & & $1 / 0.8$ & $2 / 2.0$ & & & $3 / 0.7$ \\
\hline Fistulariidae & & & & & & $1 / 0.8$ & & $1 / 2.7$ & & $2 / 0.5$ \\
\hline Nemipteridae & & & & & & $1 / 0.8$ & $1 / 1.0$ & & & $2 / 0.5$ \\
\hline Scorpaenidae & & & & & $1 / 1.7$ & & & & $1 / 6.3$ & $2 / 0.5$ \\
\hline Balistidae & & & & & & $1 / 0.8$ & & & & $1 / 0.2$ \\
\hline Chaetodontidae & & $1 / 3.2$ & & & & & & & & $1 / 0.2$ \\
\hline Creedidae & & & $1 / 6.6$ & & & & & & & $1 / 0.2$ \\
\hline Lutjanidae & & & & & & & & & $1 / 6.3$ & $1 / 0.2$ \\
\hline Monacanthidae & & & & & $1 / 1.7$ & & & & & $1 / 0.2$ \\
\hline Pinguipedidae & & & & & & & & $1 / 2.7$ & & $1 / 0.2$ \\
\hline Platycephalidae & & & $1 / 6.6$ & & & & & & & $1 / 0.2$ \\
\hline Plesiopidae & & & & & & $1 / 0.8$ & & & & $1 / 0.2$ \\
\hline Siganidae & & & $1 / 6.6$ & & & & & & & $1 / 0.2$ \\
\hline Total prey & 18 & 31 & 15 & 21 & 59 & 127 & 98 & 37 & 16 & 422 \\
\hline $\begin{array}{l}\text { Number of } \\
\text { prey families }\end{array}$ & 6 & 8 & 9 & 7 & 11 & 15 & 14 & 10 & 8 & 27 \\
\hline P. Jeopardus & & & & & & & & & & \\
\hline Number with prey & 45 & 68 & 40 & 54 & 108 & 163 & 139 & 71 & 22 & 710 \\
\hline Total number & 60 & 93 & 78 & 88 & 157 & 260 & 191 & 113 & 36 & 1076 \\
\hline
\end{tabular}

coral reefs, thus changes in the diet related to predator size were inevitable. While some aspects of the diet changed gradually with growth, other dietary changes were abrupt. There were 2 shifts in the diet of $P$. leopardus at different sizes during growth. The first was a major ontogenetic shift from a juvenile to an adult diet and such shifts are well documented in other serranids (Parrish 1987). The second was a passive shift due to no further size-related changes in their diet and, to the author's knowledge, has not been reported elsewhere.

Juvenile Plectropomus leopardus (5 to $20 \mathrm{~cm} \mathrm{SL}$ ) have a distinct diet that undergoes transitional phases to an adult $(\geq 20 \mathrm{~cm} \mathrm{SL})$ diet, when fish were con- sumed almost exclusively. Juvenile diets included benthic crustaceans (mostly penaeid shrimps) and fishes, and juveniles consumed more fish as they grew. This trend of increasing piscivory with size was also found by Light (1995) in small juvenile P. leopardus $(<10 \mathrm{~cm} \mathrm{SL})$. Juveniles of all sizes $(<20 \mathrm{~cm} \mathrm{SL})$ ate a similar composition of fish prey, the numerous and speciose benthic families on coral reefs. These dietary results were corroborated by feeding observations in other studies (Goeden 1978, Light 1995). The smallest size class ( $<6 \mathrm{~cm} \mathrm{SL}$ ) of $P$. leopardus showed the greatest dependence on benthic prey (Goeden 1978 ) and fed most frequently, attacking prey once every 3 to $5 \mathrm{~min}$ on average (Goeden 1978) and 


\begin{tabular}{|c|c|c|c|c|c|}
\hline \multicolumn{6}{|c|}{ SIZE OF P. leopardus (SL cm) } \\
\hline \multicolumn{2}{|c|}{ JUVENILES } & \multicolumn{2}{|c|}{ ADULTS } & \multicolumn{2}{|c|}{ LARGE ADULTS } \\
\hline$\triangle$ & $<10$ & $\bullet$ & $20-24.9$ & 口 & $35-39.9$ \\
\hline$\nabla$ & $10-149$ & 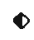 & $25-29.9$ & ע & $40-44.9$ \\
\hline$\triangleright$ & $15-19.9$ & $\bullet$ & $30-34.9$ & $\Delta$ & $45-54.9$ \\
\hline
\end{tabular}

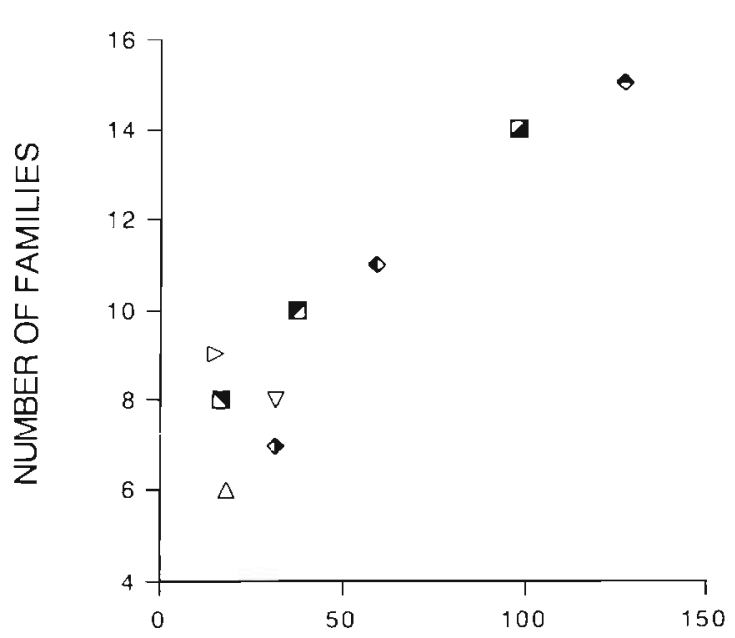

NUMBER OF IDENTIFIED PREY

Fig. 9. Plectropomus leopardus. The number of identified prey in 9 size classes of $P$. leopardus plotted against number of families in the diet. Size classes of $P$. leopardus were divided into 3 groups: juveniles $(<10,10$ to 14.9 and 15 to 19.9$)$, adults (20 to $24.9,25$ to 29.9 and 30 to 34.9 ) and large adults ( 35 to $39.9,40$ to 44.9 and 45 to $54.9 \mathrm{~cm} \mathrm{SL}$ )

spending 18 to $37 \%$ of their time foraging (Light 1995). Feeding behaviour was similar between the next 2 classes (equivalent to 10 to $20 \mathrm{~cm}$ and 19 to $31 \mathrm{~cm}$ SL) which attacked demersal or demersal-

Table 5. The families of prey fishes classified by their association with 4 broad habitats on the reef; demersal, benthic, midwater and adjacent sands (see 'Methods' for definitions)

\begin{tabular}{|llll|}
\hline Demersal & Benthic & Midwater & Adjacent Sands \\
\hline Acanthuridae & Blenniidae & Atherinidae & Callionymidae \\
Apogonidae & Gobiidae & Caesionidae & Creedidae \\
Balistidae & Scorpaenidae & Clupeidae & Nemipteridae \\
Chaetodontidae & Tripterygiidae & Engraulidae & Pinguipidae \\
Labridae & & Fistulariidae & Platycephalidae \\
Lutjanidae & & & Synodontidae \\
Monacanthidae & & & \\
Plesiopidae & & & \\
Pomacentridae & & & \\
Scaridae & & & \\
Serranidae & & & \\
Siganidae & & & \\
\hline
\end{tabular}

HABITATS OF PREY

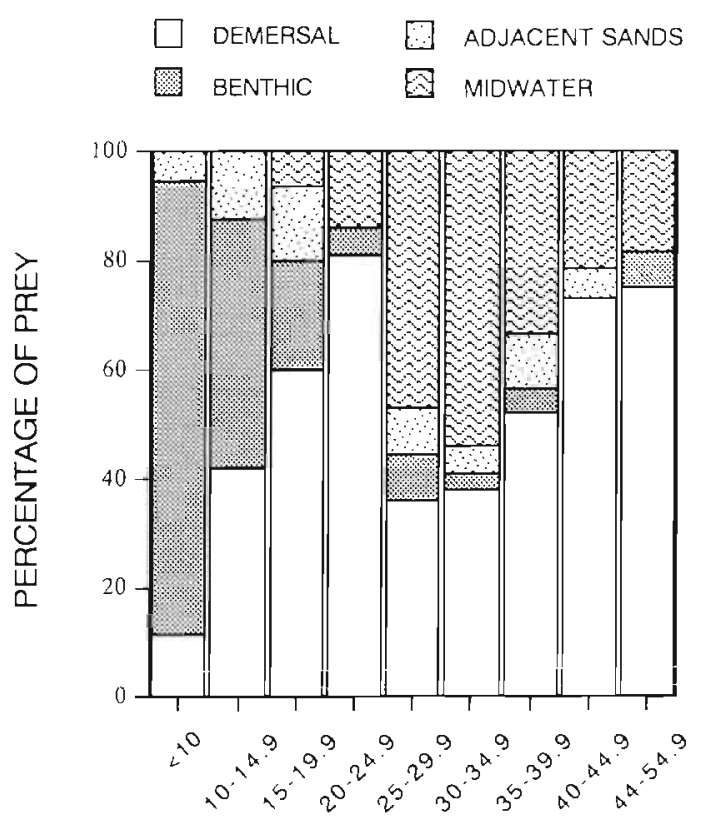

SIZE CLASSES OF P. leopardus (SL cm)

Fig. 10. Plectropomus leopardus. The numerical percentage of prey in the 4 environments, demersal and benthic reef substrata habitats, adjacent sands and midwater habitats,

that were consumed by the 9 size classes of $P$. leopardus

pelagic fishes and some invertebrates, however, the larger size class occasionally took midwater prey (Goeden 1978). Thus, $P$. leopardus is a typical closebottom dweller. Juveniles are benthic dwellers, living close to reef substrata (mostly within $30 \mathrm{~cm}$ ), whereas adults utilise demersal and demersal-pelagic habitats as well (Goeden 1978).

Plectropomus leopardus ate a wide variety of fish from 28 families during summer. The number of families of fishes in the diet did not increase with size of predator because the size range in some prey families, especially small benthic fishes (e.g. Tripterygiidae), was narrow and they were not consumed by larger fish. Also, prey in 9 families were consumed only once. Numerically, fishes of the Clupeidae, Pomacentridae and Labridae were consumed the most, and the abundance of prey per family varied among the size classes of $P$. leopardus $<35 \mathrm{~cm} \mathrm{SL}$.

Average daily consumption of prey in Plectropomus leopardus $(2.8 \%$ of total body weight) is similar to other large tropical predators: $3.6 \%$ in Epinephelus striatus (Reshetnikov et al. 1972) and $3.8 \%$ in Lutjanus 


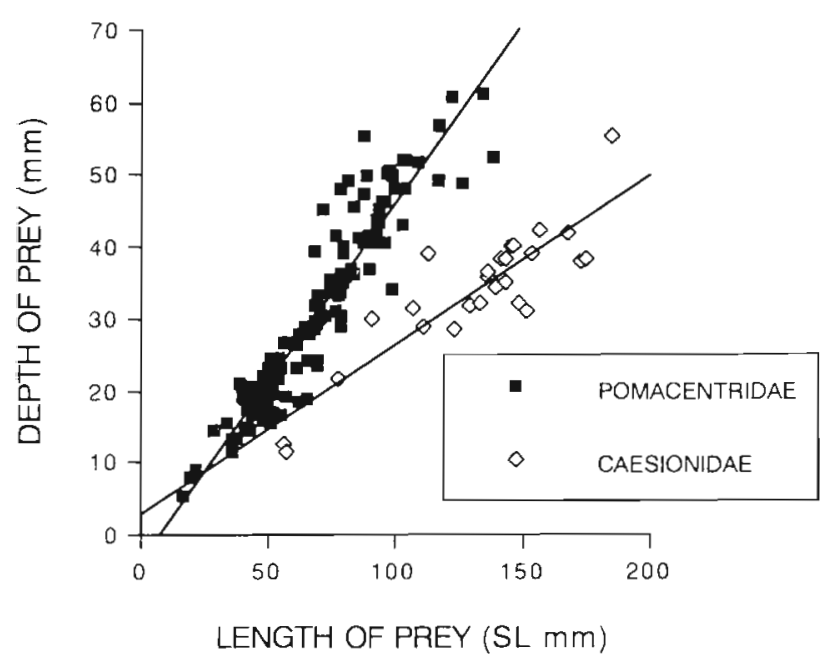

Fig. 11. The relationship between $\mathrm{SL}(\mathrm{mm})$ and maximum depth $(\mathrm{mm})$ of prey of 2 families, Pomacentridae and Caesionidae

russelli (Smith et al. 1991). Although relative prey weight increased with the size of $P$. leopardus, energetic requirements of adults were not necessarily higher because calculations were based on single prey items and juveniles compensate for eating smaller rations relative to their size by feeding more frequently.

In Plectropomus leopardus, the timing of the major change in the diet to dominant piscivory (approx. 95\%) occurred at $20 \mathrm{~cm} \mathrm{SL}$, just prior to the onset of sexual maturity (minimum size of 20 or $25 \mathrm{~cm} \mathrm{SL}$ on the northern or central GBR, respectively Brown 1994, Ferreira $\&$ Russ 1995). This change in feeding occurred at a relatively small size in $P$. leopardus (1/3 of max. adult size) compared to Atlantic cod Gadus morhua or silver hake Merluccius bilinearis (60 to $80 \%$ max. adult size; Langton 1982). Biological changes in fishes often coincide with major ontogenetic shifts in feeding. Similar to P. leopardus, sexual maturity loosely corresponds with major changes in the diet of other fishes (MacNeill \& Brandt 1990, McCormick 1998). Growth, however, remains high until $35 \mathrm{~cm}$ FL in $P$. leopardus (Ferreira \& Russ 1994) even though major ontogenetic shifts in feeding are often correlated with discrete growth periods in the life history (Werner \& Gilliam 1984).

The second major change in the diet of Plectropomus leopardus occurred at $35 \mathrm{~cm}$ SL when adults reached a size threshold beyond which there was no change in the composition of the diet and the length of fish prey, despite the fish growing another $20 \mathrm{~cm}$ in length $(1 / 3$ their maximum size $)$. This size threshold coincides with a marked slowing in growth (Ferreira \& Russ 1994). Growth may be affected by the low
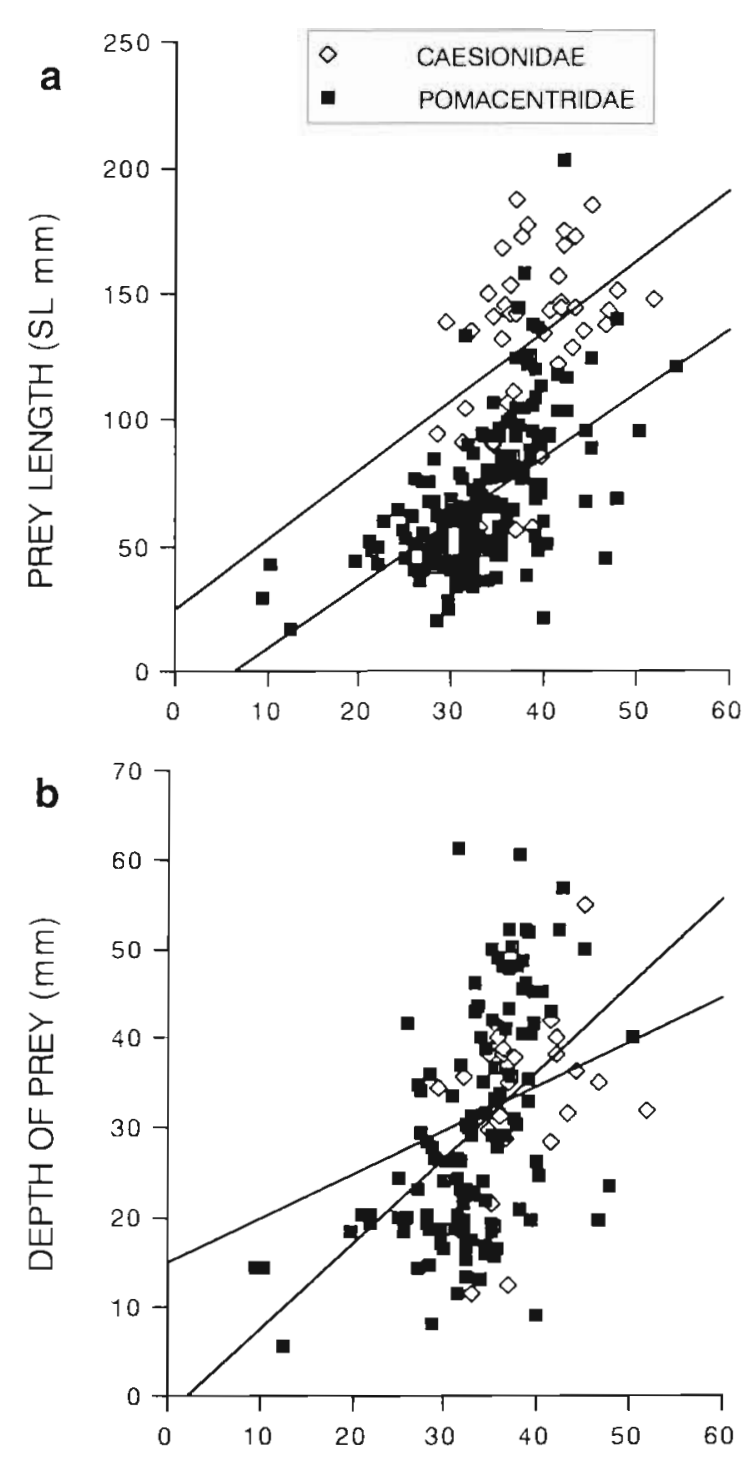

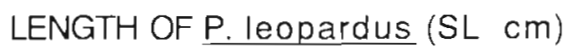

Fig. 12. (a) Plectropomus leopardus. The relationship between SL $(\mathrm{cm})$ of P. leopardus and the SL $(\mathrm{mm})$ of prey of 2 families, Pomacentridae and Caesionidae. (b) The relationship between SL $(\mathrm{cm})$ of $P$. leopardus and maximum depth $(\mathrm{mm})$ of prey of 2 families, Pomacentridae and Caesionidae

energy diet caused by a lack of increases in prey size, but this seemed unlikely as relative prey weight did not decline correspondingly and growth in all fishes slows with age. After $45 \mathrm{~cm}$ SL the depth of prey did not increase. The low depth-gape value in the largest size class ( $>45 \mathrm{~cm} \mathrm{SL}$ ) was explained by an increase in the gape of $P$. leopardus coupled with a lack of a shift to families that include larger prey. Such large, deep-bodied prey fishes may be unavailable on the GBR. 
Both SL and body depth were useful measures of prey in this study. Body depth of prey explained the consumption of prey of different shapes, but SL was the most frequent measurement of digested fish. Therefore, SL was useful to determine the size range of prey and the most common prey length (40 to $49.9 \mathrm{~mm}$ SL). Unlike the results of most studies of prey selection in fish. Plectropomus leopardus did not follow the usual clear tendency to select larger prey as they grow larger (see Gordoa \& Macpherson 1990). Choat (1968) and Kingsford (1992) concluded that larger P. leopardus eat larger prey and feed on a wider range of prey sizes, but only small to medium sized $P$. leopardus in the present study showed such a trend.

Two results suggested that body depth of prey is the most important physical factor constraining the consumption of large prey by Plectropomus leopardus on coral reefs. First, $P$. leopardus appear to feed optimally when selecting prey with deeper bodies. Werner (1974) determined an optimal size of prey based on predator gape, prey size and handling time which was a depth-gape value of 0.59 regardless of predator size. For $P$. leopardus the mean depth-gape value was 0.60 when feeding on deep bodied fish although they can swallow prey very close to their gape size (St John 1995). Second, size-related predation was similar between 2 families with differing shapes (oval pomacentrids and fusiform caesionids) when body depth, rather than length, was used. The importance of body depth of prey in predation is not uncommon. Prey body depth is an important factor affecting predator-prey interactions of largemouth bass (Webb 1986) and a hybrid pike (Moody et al. 1983). Thus, future studies on coral reefs that examine prey size in predation should consider prey depth and shape, in addition to length.

Plectropomus leopardus consumed a wide variety of fishes in families that lived in all 4 broad habitats on coral reefs: adjacent sands, midwater, benthic reef substrata and demersal reef substrata. This variety in the diet reflected the ontogenetic change in feeding behaviour (described earlier, Goecien 1.978) and the large home ranges of adult fish (Samoilys 1997, Zeller 1997 ) that included several habitats (Goeden 1978. Kingsford 1992, Samoilys 1997). Average prey shape varied among habitats and was not related to feeding by $P$. leopardus. Prey associated with the demersal reef substrata. were deeper bodied than prey in the midwater habitat or adjacent sands. Yet, $P$. leopardus fed mostly from the demersal and midwater habitats, and all size classes consumed the least prey from adjacent sands between reefs.

Prey selection within these habitats appeared to depend on several factors. Two of these factors were size and shape of prey, but their importance in predation by Plectropomus leopardus varied among habi- tats. Size related predation by juveniles occurred in the benthic habitat where the shape of prey fish did not differ from prey fish in other habitats. Juvenile P. leopardus fed from the benthic habitat exclusively, but consumed more slender prey fish (on average) than adults and thereby avoided gape limitation. In the midwaters, abundances of slender, small schooling fishes in the diet of $P$. leopardus suggested that size-related predation in $P$. leopardus was easily decoupled by the presence of these fishes in large schools. Small, slender, schooling Clupeidae were eaten by a wide size range of $P$. leopardus (15 to $55 \mathrm{~cm} \mathrm{SL}$ ) although the middle size ranges (25 to $39.9 \mathrm{~cm} \mathrm{SL}$ ) consumed the most. Other studies have reported that $P$. leopardus consume small schooling fishes when available (Choat 1968, St John 1995). The diet of $P$. leopardus contained a high percentage of atherinids when specimens were speared from a group that had been clustering around the periphery of schools of Pranesus capricornesis (Choat 1968). Feeding by P. leopardus on small schooling fishes in the midwaters is not related to size and can be explained by changes in feeding preferences. Large schools of small fishes are temporally variable (affecting their availability), highly visible and mobile on coral reefs, and in many fishes these 3 attributes altered size-related preferences in feeding (Main 1985, Gordoa \& Macpherson 1990).

Plectropomus leopardus is one of the most highly piscivorous serranids and, like many of its family, this predator becomes more piscivorous with increasing size (Parrish 1987). Size-dependent shifts in diet similar to those observed for $P$. leopardus have been documented in other species of tropical serranids: Mycteroperca rosacea (Hobson 1965), Epinephelus merra (Harmelin-Vivien \& Bouchon 1976), Epinephelus striatus (Randall 1965) and 3 species of Cephalopholis (Shpigel \& Fishelson 1989). Also, P. leopardus are like less piscivorous serranids, such as E. merra (HarmelinVivien \& Bouchon 1976), because at larger sizes they eat cephalopods.

The major annual recruitment of reef fishes to the GBR occurs in summer and the study was done during this season because prey of all sizes were available to Plectropomus leopardus. The results of this study, however, were not affected by its restricted sampling period because St John (1995) found no major seasonal trends in the diet of $P$. leopardus on a mid-shelf reef on the central GBR. In this study Plectropomus leopardus were collected from numerous reefs to obtain adequate sample sizes of all size classes. Most $P$. leopardus were collected from reefs within a $200 \mathrm{~km}$ length of the GBR and assemblages of prey fishes were assumed to be similar among habitats on reefs throughout this area. Prey availability was not assessed due to the large size of the study area, the mobility of $P$. leopardus and the 
wide range of prey species consumed. Knowledge of the densities of prey families and their size, however, would help explain the dietary patterns found in this study. For example, dietary results of $P$. leopardus $<10 \mathrm{~cm}$ SL differed between Light's (1995) and the present study even though specimens were collected from the same site. Pomacentridae was the most common family (30 out of 48 identified fish) in Light's (1995) study, but was absent in the diet of $P$. leopardus $<10 \mathrm{~cm}$ $\mathrm{SL}$ in the present study. Gobiidae dominated the diet in the present study and ranked second in Light's (1995) study. As samples for the 2 studies were collected over different years, annual differences in availability of small Pomacentridae, due to variations in their recruitment (e.g. Doherty \& Fowler 1994), may best explain their absence in the present study.

The size threshold in the diet of adult Plectropomus leopardus has implications for its fishery and ecology. Before entering the fishery (minimum legal size is $37 \mathrm{~cm}$ TL or $32 \mathrm{~cm} \mathrm{SL}$, Table 2) at around 3 yr of age (Ferreira \& Russ 1994), juvenile and young adult $P$. leopardus eat a varied and size-dependent diet. After entering the fishery, however, the diet of $P$. leopardus of all sizes does not vary. Thus, size structure of populations are not important when considering food resources of the fishery. Consequently, the feeding ecology of this species will not be affected by variations in the size structure of fished populations due to strong inter-annual fluctuations in recruitment that are maintained in the population (Russ et al. 1996) or changes in the size structure of the catch of $P$. leopardus resulting from new commercial ventures such as the live fish fishery (Richards 1993) which targets smaller plate-sized fish (Miles 1997). From an ecological perspective, the size threshold at $35 \mathrm{~cm}$ SL means that $P$. leopardus are utilising the same food resource for most of their life. After attaining $35 \mathrm{~cm} \mathrm{SL}, P$. leopardus may live for more than 9 yr (Ferreira \& Russ 1994) consuming on average $2.8 \%$ of their total body weight daily. Predation over this time span suggests that, at high densities, P. leopardus may impact local populations of their common prey. The importance of such an impact and whether density or size structure of prey populations are affected, remains to be tested.

Acknowledgements. The following people provided stomach samples: J. Bibby, I. Brown, C. Davies, P. Doherty, B. Ferreira, P. Laycock, P. Light, M. Samoilys, H. Sweatman, L. Squires and members of the Townsville Skin Diving Club. Garry Russ, Hugh Sweatman, Jeff Leis, Bill Gladstone, Jean Deklerk and 4 anonymous referees improved the manuscript considerably. Hugh Sweatman repeated some statistical analyses. My gratitude and thanks to everyone. This research was supported by the Australian Federation of University Women, Qld, the Great Barrier Reef Marine Park Authority and the Coral Reef Society.

\section{LITERATURE CITED}

Allen GR (1975) Damselfishes of the South Seas. TFH Publications, Neptune City, New Jersey

Austin $\mathrm{H}$, Austin $\mathrm{S}(1971)$ The feeding habits of some juvenile marine fishes from the mangroves in Western Puerto Rico. Carib J Sci 11(3-4):171-178

Ayling AM, Ayling AL (1992) Effects of fishing pilot study: visual surveys on Cairns section closed reefs that will be opened under the new zoning plan. Great Barrier Reef Marine Park Authority, Townsville

Brown IW (1994) Growth, reproduction and recruitment of Great Barrier Reef food fish stocks. Fisheries research and development corporation project no. 90/18. Southern Fisheries Centre, Queensland Department of Primary Industries, Deception Bay

Choat JH (1968) Feeding habits of and distribution of Plectropomus maculatus (Serranidae) at Heron Island. Proc R Soc Qd 80(2):13-18

Cohen DM (1970) How many recent fishes are there? Proc California Acad Sci 38:341-346

Connell SD (1998) Patterns of piscivory by resident predatory reef fish at One Tree Reef, Great Barrier Reef. Mar Freshw Res 49:25-30

Connell SD. Kingsford MJ (1997) The utility of descriptive information for assessing the impact of coral reef piscivores on their prey. Proc 8th Int Coral Reef Sym Panama 1: 999-1004

Day RW, Quinn GP (1989) Comparisons of treatments after an analysis of variance in ecology. Ecol Monogr 59: $433-463$

Doherty PJ, Fowler T (1994) An empirical test of recruitment limitation in a coral reef fish. Science 263:935-939

Doherty PJ, Fowler AJ, Samoilys MA, Harris DA (1994) Monitoring the replenishment of coral trout (Pisces: Serranidae) populations. Bull Mar Sci 54(1):343-355

Ferreira BP, Russ GR (1994) Age validation and estimation of growth rate of the coral trout Plectropomus leopardus (Lacepede 1802) from Lizard Island, Northern Great Barrier Reef. Fish Bull 92:46-57

Ferreira BP, Russ GR (1995) Population structure of the leopard coralgrouper, Plectropomus leopardus, on fished and unfished reefs off Townsville, Central Great Barrier Reef, Australia. Fish Bull 93:629-642

Galis F (1993) Morphological constraints on behaviour through ontogeny: the importance of developmental constraints. Mar Behav and Physiol 23:119-135

Goeden GB (1978) A monograph of the coral trout Plectropomus leopardus. Res Bull Qld Fish Ser 1:42

Gordoa A, Macpherson E (1990) Food selection by a sit-andwait predator, the monkfish Lophius upsicephalus, off Namibia (South West Africa). Env Biol Fishes 27:71-76

Hambright KD (1991) Experimental analysis of prey selection by largemouth bass: role of predator mouth width and prey body depth. Trans Am Fish Soc 120:500-508

Harmelin-Vivien ML, Bouchon C (1976) Feeding behavior of some carnivorous fishes (Serranidae and Scorpaenidae) from Tulear (Madagascar). Mar Biol 37:329-340

Hobson ES (1965) Diurnal-nocturnal activity of some inshore fishes in the Gulf of California. Copeia 291-302

Kingsford MJ (1992) Spatial and temporal variation in predation on reef fishes by coral trout (Plectropomus leopardus Serranidae) Coral Reefs 11:193-198

Langton RW (1982) Diet overlap between Atlantic Cod Gadus morhua silver hake Merluccius bilinearis and fifteen other northwest Atlantic finfish. Fish Bull 80(4):745-759

Leis JM (1987) Review of the early life history of tropical 
groupers (Serranidae) and snappers (Lutjanidae) In: Polovina JJ, Ralston S (eds) Tropical snappers and groupers: biology and fisheries management. Westview Press Inc. Boulder, Colorado, p. 189-237

Light PR (1995) The early life history of coral trout Plectropomus leopardus at Green and Arlington Reefs. PhD thesis, James Cook University of North Queensland, Townsville, Australia

Light PR, Jones GP (1997) Habitat preference in newly settled coral trout (Plectropomus leopardus, Serranidae). Coral Reefs 16:117-126

MacNeill DB, Brandt SB (1990) Ontogenetic shift in gill raker morphology and predicted prey capture efficiency of the alewife Alosa psuedoharengus. Copeia 1990:164-171

Main KL (1.985) The influence of prey identity and size on selection of prey by two marine fishes. J Exp Mar Biol Ecol 88: $145-152$

Manly BFJ (1991) Randomization and Monte Carlo methods in Biology. Chapman and Hall, London

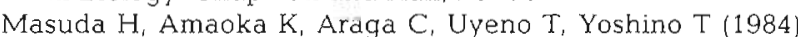
The fishes of the Japanese archipelago. Tokai University Press, Tokyo

McCormick MI (1998) Ontogeny of diet shifts by a microcarnivorous fish, Cheilodactylus spectabilis: relationships between feeding mechanics, microhabitat selection and growth. Mar Biol 132:9-20

Mehta C, Patel N (1992) StatXact. CYTEL Software Corporation, Cambridge

Miles A (1997) Research, not rumors, needed for live fishing industry. Exploring reef science. May newsletter. CRC Reef Research Centre James Cook University, Townsville, Australia

Moody RC, Helland JM, Stein R A (1983) Escape tactics used by bluegills and fathead minnows to avoid predation by tiger muskellunge. Env Biol Fish 8(1):61-65

Mummert JR, Drenner RW (1986) Effect of fish size on the filtering efficiency and selective particle ingestion of a filterfeeding clupeid. Trans Am Fish Soc 115:522-528

Myers RF (1991) Micronesian reef fishes: a practical guide to the identification of the inshore marine fishes of the tropical and central Pacific 2nd edn. Coral Graphics, Barrigada, Guam

Parrish JD (1987) The trophic biology of snappers and groupers In: Polovina JJ, Ralston S (eds) Tropical snappers and groupers: biology and fisheries management. Westview Press Inc. Boulder, Colorado, p 405-463

Randall JE (1965) Food habits of the Nassau grouper (Epinephelus striatus) 6th meeting. Assoc Island Mar Labs Caribb 6:13-16

Randall JE, Hoese DF (1986) Revision of the groupers of the Indo-Pacific genus Plectropomus (Perciformes; Serranidae). Indo-Pacific Fishes 13:1-31

Randall JE, Allen GR, Steene RC (1990) Complete diver's and fisherman's guide to fishes of the Great Barrier Reef and Coral Sea. Crawford House Press, Bathurst

Reshetnikov YS, Claro R, Silva A (1972) The pattern of feeding and the rate of digestion in some tropical predatory fish. J Ichthyol 12:818-824

Richards A (1993) Live reef fish exports to South-East Asia from the South Pacific. SPC Fish Newsl 67:34-36

Russ GR, Lou DC, Ferriera BP (1996) Temporal tracking of a strong cohort in the population of a coral reef fish, the

Editorial responsibility: Otto Kinne (Editor),

Oldendorf/Luhe, Germany coral trout, Plectropomus leopardus (Serranidae: Epinephelinae), in the central Great Barrier Reef, Australia. Can J Aquat Sci 53:2745-2751

Sale PF (1991) The ecology of fishes on coral reefs. Academic Press, San Diego

Samoilys MA (1997) Movement in a large predatory fish: coral trout Plectropomus leopardus (Pisces: Serranidae) on Heron Reef, Australia. Coral Reefs 16:151-158

Schael DM, Rudstam LG, Post JR (1991) Gape limitation and prey selection in larval yellow perch (Perca flavescens) freshwater drum (Aplodinotus grunniens) and black grappie (Pomoxis nigromaculatus). Can J Fish Aquat Sci 48: $1919-1925$

Shpigel M, Fishelson L. (1989) Habitat partitioning between species of the genus Cephalopholis (Pisces Serranidae) across the fringing reef of the Gulf of Aqaba (Red Sea). Mar Ecol Prog Ser 58:17-22

Smith MM, Heemstra PC (1986) Smiths' sea fishes. SpringerVerlag, Berlin

Smith R, Salini JP, Blaber SJM (1991) Food intake and growth in the Moses perch Lutjanus russelli (Bleeker) with reference to predation on penaeid prawns. J Fish Biol 38: $897-903$

Sokal RR, Rohlf FJ (1981) Biometry 2nd edn. WH Freeman, San Francisco

St John J (1995) Feeding ecology of the coral trout Plectropomus leopardus (Serranidae) on the Great Barrier Reef, Australia. PhD thesis, James Cook University of North Queensland, Townsville, Australia.

Trainor N (1991) Commercial line fishing. The Queensland Fisherman. March 1991:17-25

Underwood AJ (1981) Techniques of analysis of variance in experimental marine biology and ecology. Oceanogr Mar Biol Ann Rev 19:513-605

Wainwright PC (1988) Morphology and ecology: functional basis of feeding constraints in Caribbean Labrid fishes. Ecology 69(3):635-645

Webb PW (1986) Effect of body form and response threshold on the vulnerability of four species of teleost prey attacked by largemouth bass (Micropterus salmoides). Can J Fish Aquat Sci 43:763-771

Werner EE (1974) The fish size prey size handling time relation in several sunfishes and some implications. J Fish Res Board Can 31:1531-1536

Werner EE (1977) Species packing and niche complementarity in three sunfishes. Am Nat 111:553-578

Werner EE, Gillam JF (1984) The ontogenetic niche and species interactions in size-structured populations. Ann Rev Ecol Sys 15:393-425

Williams DM, Russ GR (1994) Review of data on fishes of commercial and recreational fishing interest on the Great Barrier Reef. Research Publication No. 33. Great Barrier Reef Marine Park Authority, Townsville, Australia

Zaret TM (1980) Predation and freshwater communities. Yale University Press, New Haven

Zeller DC (1997) Home range and activity patterns of the coral trout Plectropomus leopardus (Serranidae). Mar Ecol Prog Ser 154:65-77

Zeller DC (1998) Spawning aggregations: patterns of movement of the coral trout Plectropomus leopardus (Serranidae) as determined by ultrasonic telemetry. Mar Ecol Prog Ser 162:253-263

Submitted: September 9, 1998; Accepted: October 15, 1998 Proofs received from author(s): April 6, 1999 